\title{
THE EFFECT OF BUDGET PARTICIPATION ON MANAGERIAL PERFORMANCE WITH COST MANAGEMENT KNOWLEDGE AS A MODERATED VARIABLES
}

\author{
Sharon Kristiani \\ Widya Mandala Surabaya Catholic University \\ sharonkristianitjahjono@gmail.com
}

\author{
A R T I C L E I N F O \\ Article history: \\ Received: 29 April 2021 \\ Revised: 3 June 2021 \\ Accepted: 9 Juni 2021 \\ c) (7) (2)
}

Keywords:

Budget participation; cost management knowledge; managerial performance

DOI:

https://doi.org/10.33508/rima.v4i2.3151

\begin{abstract}
A B S T R A C T
This study empirically examines the effect of budget participation on managerial performance and the moderating effect of cost management knowledge on the effect of budget participation on managerial performance. The population and sample in this study are middle and lower-level managers in manufacturing companies in East Java, Indonesia, who met the criteria. The sampling technique was convenience sampling with a sample of 83 people. The research hypothesis was tested using multivariable regression analysis. The results showed that the higher the level of budget participation, the higher the managerial performance. The high level of participation is accompanied by the high knowledge of managers about cost management affecting managerial performance. Thus, this research shows that budget participation affects managerial performance. Further research on the variable cost management knowledge found that knowledge of cost management as a quasi-moderator moderates the relationship between budget participation and managerial performance.
\end{abstract}

\section{INTRODUCTION}

Economic changes that are global and comprehensive in almost all aspects are why companies are required to increase the effectiveness of the operations and performance of their companies. Goods and services freely enter and exit from one country to another. This changing environmental condition causes managers to need tools to coordinate and plan their resources limited (Aziz, 2014).

This tool is known as a budget. Budgets are company activities that are systematically compiled and expressed in monetary units and for a certain period in the future ((Dharmanegara, 2018). Managers must understand the preparation of a reasonable budget so that we need a picture of all operational activities of the company. One form of budgeting involving subordinates is a participatory budget.
Budget participation is a process in which a manager must be involved and influence determining a budget (Shields and Shields, 1998). Budget participation has become the topic of various researches in the field of Management Accounting. The first research was conducted by Argyris (1952), who examined participative impacts budgeting against the behavior of subordinates. Argyris (1952) stated that subordinates also have the right to have the opportunity to participate in the budget preparation process.

Cost management is a system that provides information for management to identify an opportunity to make improvements, plan strategies, and make decisions about procurement and the required resources used by a company. The purpose of cost management is that the operational costs that have existed in the identification, effectiveness, and efficiency 
are determined, future performance is improved, and the last is that it must achieve the three previous goals with the existence of adequate technological changes. Therefore, knowledge of cost management is essential. In addition, if a manager has implemented knowledge of cost management, the resulting performance will be seen. Therefore, the performance referred to here is managerial performance.

Managerial performance is an important thing. The existence of excellent managerial performance can create competitive advantages and improve the quality of work produced. Conversely, poor managerial performance applied by a company can have an impact on work results and costs incurred by the company. Managerial performance is a factor where the achievement of a goal of the organization during a specific period results from individuals and groups working in the organization.

Much managerial performance is associated with budgetary participation in previous studies, such as research conducted by Farahmita (2013), which examines individual satisfaction and knowledge of cost management on relationships between budget participation and managerial performance. These studies show that knowledge of cost management and job satisfaction has an impact on managerial performance. Therefore, without an opportunity to provide participation, knowledge of high-cost management, and high job satisfaction will certainly impact decreasing managerial performance.

Agbejule and Saarikoski (2006) also researched the relationship between budget participation with managerial performance. They used knowledge of cost management as a moderating variable. The results of this study suggest that managers' cost management knowledge, and especially a balanced perspective of cost management knowledge, moderate the effect of budget participation on managerial performance.
This study is a replication of research conducted by Agbejule and Saaroski (2006). The difference lies in the respondents who will be sampled. Agbejule and Saaroski's (2006) research uses middle-level managers, namely managers representing 15 different business units in companies from different Finnish manufacturing sectors. Meanwhile, this study used respondents with a sample of manufacturing companies in East Java, Indonesia. In addition, this study also seeks to prove the conceptualization of Blumberg and Pringle (1982), which describes the predicted performance results of applying the dimensions of capacity, willingness, and opportunity.

Following Blumberg and Pringle's (1982), this study selected the dimension of capacity, namely knowledge of cost management, the opportunity dimension, namely budget participation, and the willingness dimension, namely managerial performance, using a sample of middle and lower-level managers in the company manufacturing in East Java, Indonesia. The sample was chosen because a manager at the middle and lower levels was a manager who should have participated in the compilation of company budgets. The manufacturing industry in East Java contributed $14.64 \%$ of local revenue ("East Java Regional Economic and Financial Studies," 2018).

\section{LITERATURE REVIEW AND HYPOTHESIS DEVELOPMENT}

\section{Contingency Theory}

Contingency theory, often referred to as situational theory, is a situation where the environment and situation are uncertain. A leader must be able to adapt to the conditions and environment that are happening at that time. For example, organizational control operating procedures are described by the optimal forms of organizational control under different operating conditions identified through a contingency theory approach (Sartika, 2017). Contingency theory reveals if the components of an organization or company must have a match or similarity 
with one another: management accounting, situation based on contingency theory.

Contingency theory has been widely used in research to analyze and design control systems, especially in management accounting (Maharani, 2009). The relationship of the contingency theory with this research is that the environmental conditions faced are uncertain, so that it must adjust to the circumstances so that the contingency theory is used to evaluate the relationship between budgetary participation to improve managerial performance by using cost management knowledge moderator.

\section{Performance Theory}

Performance is a description of the performance of employees in achieving the goals of the organization. According to Blumberg and Pringle's (1982) research, many studies only link one or two variables with individual performance. Dimensions of capacity, willingness, and opportunity affect the performance of individuals. Blumberg and Pringle (1982) put forward the theoretical framework: Performance $=f($ Capacity $x$ Willingness $x$ Opportunity). The performance will affect if one dimension is at a lower or higher point.

The capacity dimension consists of ability, age, health, knowledge, skills, intelligence, education level, endurance, stamina, energy level, motor skills. Finally, the dimensions of willingness consist of motivation, job satisfaction, job status, anxiety, legitimacy of participation, attitudes, perceived task characteristics, job involvement, ego involvement, self-image, personality, norms, values, perceived role expectations, feelings, or equity. However, Blumberg and Pringle's research results still require further testing regarding the interaction between dimensions.

\section{Managerial Performance}

Managerial performance measures an organization's efficiency and effectiveness, which makes it an important thing. Managerial performance is an ability possessed by management to carry out every activity in achieving the company's goals. Therefore, the performance of company members in carrying out managerial activities such as planning, investigating, coordinating, evaluating, supervising, managing staff, negotiating, and represent are part of the managerial performance (Nasution, 2005).

\section{Budget Participation}

The company aims to prepare a budget, namely to monitor every existing operational and financial activity in the future. In other words, participation is the alignment of goals that will be carried out with the goals that the company will achieve effectively and efficiently. Therefore, the intended purpose is a budget.

The budget estimates the performance time that the organization must achieve within a certain period based on financial measures (Mardiasmo, 2002). At the same time, Mowen and Hansen (2004) regretted emphasizing that the financial plan for the future identifies the organization's goals and what actions are needed to achieve them. The benefits of budgeting include 1) As a tool for managers to plan, 2) Improving decision making, it is necessary to provide information, 3) Providing standards in performance appraisal, and 4) Improving communication and coordination.

\section{Cost Management Knowledge}

Philosophy for undertaking continuous improvement to improve services through the achievement of organizational goals and the determination of decisions from management is a proactive attitude based on any production costs that are applied at an efficient cost, or low cost is the definition of cost management.

The level of knowledge about cost management can affect the consequences of performance. According to Scully (1995), the quality of performance can be reduced due to the quality of low-cost management knowledge. Therefore, the company's costs 
need to be grouped according to several things: the cost of resources, operational costs, and costs related to the company. Because with this cost differentiation, the company can minimize unnecessary costs, and there can be better accountability for the company's finances.

\section{Hypothesis Development}

1) The Effect of Budget Participation on Managerial Performance

Optimal forms of organizational control under different operating conditions are tried to explain how organizational control operating procedures are identified through a contingency theory approach (Sartika, 2014). Managers must respond quickly to this situation of environmental uncertainty by processing existing information. The higher the level of environmental uncertainty, the more information is required for decision-making.

Based on the research results conducted by Zubir et al. (2016), budget participation has a positive effect on managerial performance. Zubir et al. (2016) succeeded in proving that budget participation significantly affects managerial performance. The Agbejule research and Saarikoski (2006) also states that budget participation has a positive effect on managerial performance. Budget participation will benefit the organization by providing suitable facilities so that it will increase performance. Furthermore, efficient and effective budget participation can motivate employees to meet organizational goals to improve existing performance in the company.

H1: Budget participation has a positive effect on managerial performance.

2) The Influence of Cost Management Knowledge as a Moderation Variable between Budget Participation and

\section{Management Performance}

The optimal forms of organizational control under different operating conditions are attempted to describe how the organization's operating control procedures are identified through a contingency theory approach (Sartika, 2014). Managers must respond quickly to this situation of environmental uncertainty by processing existing information. The higher the level of environmental uncertainty, the more information is needed by management for decisionmaking. Agbejule and Saarikoski (2006) use the theoretical framework of Blumberg and Pringle (1982) with three dimensions: capacity, willingness, and opportunity.

Research conducted by Agbejule and Saarikoski (2006) states that if managers' knowledge of cost management increases, budget participation in managerial performance will also be more positive. The influence of higher cost management strengthens the positive effect of budget participation on managerial performance. Because the level of knowledge about cost management can affect the consequences of performance, cost management knowledge possessed by individuals will reduce the quality and performance generated for the company.

Farahmita (2013) states that cost management knowledge strengthens the positive influence of budget participation on performance. Conversely, knowledge of cost management without budget participation will reduce managerial performance. Zubir et al. (2016) supported this conclusion, which states that knowledge of cost management as a moderating variable can moderate the relationship between budget participation and managerial performance.

$\mathrm{H} 2$ : Knowledge of cost management moderates the effect of budget participation on managerial performance. 


\section{RESEARCH METHODS}

Based on the hypothesis, the following is a model of the analysis used in this study:

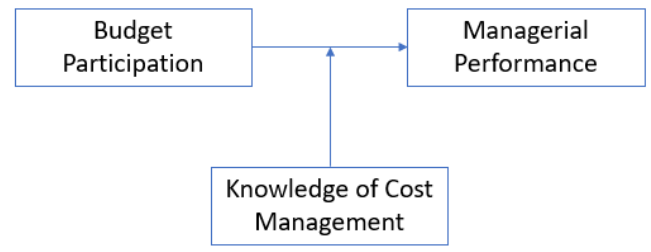

Figure 1. Conceptual Framework

\section{Research population and sample}

The population of this research is middle and lower-level managers in manufacturing companies in East Java, Indonesia. The reason for choosing this population is that middle and lower-level managers should participate in preparing the company budget.

This research was conducted at manufacturing companies in East Java, Indonesia, because the manufacturing industry in East Java contributed $14.64 \%$ of local revenue ("East Java Regional Economic and Financial Studies," 2018). They were taking samples from this population using the same convenience technique.

The unit of analysis in this study is middle and lower-level managers of manufacturing companies in East Java, Indonesia, with the following criteria:

1. Work at large manufacturing companies in East Java.

2. Occupy a middle or lower-level manager, a supervisor, assistant manager, or body manager.

3. He has worked less than two years as a manager and already understands the budget mechanism that applies to the workplace and can measure its performance.

4. Respondents do not have to come from the accounting, finance, or budget division only.

\section{Research variable}

The independent variable in this study is budget participation, and the moderation variable in this study is knowledge of cost management. The dependent variable in this study is managerial performance

\section{Independent Variable}

Budget participation is a budget formulation process in which lower-level managers participate and set budget targets and influence budget achievement. These variables will be measured using instruments obtained from Agbejule and Saarikoski (2006), Farahmita (2013), and Yusfaningrum and Ghozali (2005). This instrument contains 6 (six) question items. The scale used in this study is a semantic differential scale, which has a value of 1 to 5 . The level of budget participation of each respondent will be obtained from the average score of all questions.

\section{Moderation Variables}

Knowledge of cost management is developing or using the information in cost management to implement the organizational strategy. This variable will be measured using Agbejule and Saarikoski (2006) and Farahmita (2013). This instrument contains 7 (seven) question items. The questions asked are only about the manager's cost management knowledge is good or not, his ability is good or not, and the like. The scale used in this study is the Likert scale, which has a value of 1 (strongly disagree) to 5 (strongly agree). The level of knowledge of cost management of each respondent will be obtained from the average score of all questions.

\section{Dependent Variable}

Managerial performance is the extent to which a manager carries out management functions. Managerial performance is based on management functions, including planning, investigating, coordinating, evaluation, supervision, staff selection, negotiation, and representation. This variable is measured using an instrument used by Agbejule and Saarikoski (2006) and Farahmita (2013). 
Measurement of managerial performance is using the self-perceptions rating method. The elements measured are planning, investigating, coordinating, evaluating, supervising, staffing, negotiating, and representing. The measurement scale used a Likert scale, starting from 1 (one), which means significantly disagree until 5 (five), indicating very agree. The managerial performance of each respondent will be measured using the average score of all statements.

\section{Data analysis technique}

The equation model used in this study is multivariable regression. The multivariable regression equation models in this study are:

$$
\mathrm{KM}=\alpha+\beta 1 \mathrm{PA}+\beta 2 \mathrm{PMB}+\beta 3 \mathrm{PA} * \mathrm{PMB}+\varepsilon
$$

\section{Information:}

$$
\begin{array}{ll}
\text { KM } & =\text { Managerial Performance } \\
\mathbf{a} & =\text { Constant } \\
\beta 1,2,3 & =\text { Regression coefficient } \\
\text { PA } & =\text { Budget Participation } \\
\text { PMB } & =\text { Cost Management Knowledge } \\
\varepsilon & =\text { Error }
\end{array}
$$

The tool used to measure the independent variable $(X)$ contribution to the dependent variable $(\mathrm{Y})$ is the coefficient of the determination test. If the coefficient of determination (R2) is more significant (close to one), it indicates the better the ability of variable $X$ to explain variable $Y$ where $0<\mathrm{R} 2<1$.

Conversely, if $\mathrm{R} 2$ is getting small (close to zero), the independent variable's effect is small on the dependent variable. This value means that the model used is not strong enough to explain the effect of the independent variables under study on the dependent variable. Then the $\mathrm{F}$ test is carried out to test the model's accuracy and see whether all the independent variables are included in the model have a joint influence on the dependent variable.
Meanwhile, to test hypothesis one (H1) to hypothesis two $(\mathrm{H} 2)$ or to find out how far the influence of an independent variable partially (individually) on the variation of the dependent variable is carried out a partially significant test.

\section{RESULTS AND DISCUSSION}

Statistic Descriptive

The Budget Participation Variable (PA) with 83 respondents has a minimum value of 16 and a maximum value of 30 . The average value is 24.09 and a standard deviation of 2.953. Therefore, the budget participation variable would use six-question items if six respondent questions answered an average of 24.09 using a semantic differential.

It means that they tend to answer on a scale of 4 , which means that the level of budget participation from respondents is high, which means that the respondent participates in budgeting. that is in the company. Therefore, respondents are pretty familiar with the existing budgets within the company because respondents are involved in preparing the company budget.

The variable cost management knowledge (PMB) with 83 respondents has a maximum value of 35 and a minimum value of 21 . The average value amounts to 30.83 and a standard deviation of 2.527. The knowledge variable of cost management uses 7 (seven) questions and a Likert scale of 1 to 5. It means that if 7 (seven) questions the respondent answers an average of 30.83 on a scale of 4 , it concludes that respondent cost management knowledge is high, which means that respondents use information related to cost management to be implemented in the company's strategy.

The managerial performance variable (KM) with 83 respondents has a value. The maximum value is 45 , and the minimum value is 28 . The average value is 38.49 , and the standard deviation is 2.928. The managerial performance variable uses 9 (nine) question items and a Likert scale of 1 
to 5. It means that if 9 (nine) questions of the respondent answer an average of 38.49 , it concludes that the managerial performance level of the respondent is high.

It means that the level of managerial performance of the respondent in the company is quite good and satisfying because it has carried out the functions that have been determined and exist in the company.

\section{Validity Test and Reliability Test}

The validity test is used to measure a statement used to have a valid character expressed in the questionnaire, while the reliability test to measure how much something is measured is consistent and stable. Budget participation variable (PA), knowledge of cost management (PMB), and managerial performance $(\mathrm{KM})$ are valid because they have a significant value $<0.05$. If a data has a Cronbach's Alpha value $>0.60$, it can be said that it is reliable.

On the other hand, if the data has a Cronbach's Alpha value $<0.60$, then the data is not reliable. However, data from Budget Participation (PA), Knowledge of Cost Management (PMB), and Managerial Performance (KM) have been reliable. This reliability can be proven through the results of Cronbach's Alpha for each variable. Namely, Budget Participation has a Cronbach's Alpha result of 0.868; knowledge of Cost Management has a Cronbach's Alpha result of 0.860; and Managerial Performance has a Cronbach's Alpha result of 0.801 .

Therefore, the three variables, Budget Participation (PA), Knowledge Management Costs (PMB), and Managerial Performance (KM), have a Cronbach's Alpha value> 0.60.

\section{Classic assumption test}

Normality Test and Heteroscedasticity Test

The results of the normality test state that the Kolmogorov-Smirnov $\mathrm{Z}$ value is 0.962 with a significance of 0.313 , which means that the data used in this research is usually distributed because it has a significant value from the normality test> 0.05 .

In the Glejser test, PA is Budget Participation, $\mathrm{PMB}$ is Cost Management Knowledge, and PA_PMB is the multiplication between PA and PMB. In this study, the findings showed that the regression model is free from heteroscedasticity problems, which can be proven by the sig coefficient of each variable> 0.05 .

Table 1.

The Results of The Determination

\begin{tabular}{|c|c|c|}
\hline Model & t & Sig. \\
\hline 1 (Constant) & 0.643 & 0.522 \\
\hline PA & -0.483 & 0.631 \\
\hline PMB & -0.564 & 0.574 \\
\hline
\end{tabular}

\section{Coefficient Test}

The coefficient of determination test is useful for measuring the variation in the dependent variable, which can be described by the variation in the independent variable in the linear regression model. If the smaller the $\mathrm{R} 2$ value, the independent variable has limitations in explaining the dependent variable. On the other hand, if the higher $\mathrm{R} 2$, the independent variable is able, and there are no limitations in explaining the dependent variable. With Model 1: $\mathrm{KM}=\mathrm{a}$ $+\beta 1 \mathrm{PA}+\beta 2 \mathrm{PMB}+\varepsilon$ and Model 2: $\mathrm{KM}=\alpha$ $+\beta 1 \mathrm{PA}+\beta 2 \mathrm{PMB}+\beta 3 \mathrm{PA}$ * $\mathrm{PMB}+\varepsilon$. that the R Square test is 0.740 in Model 1.

Model 1 is Budget Participation on Managerial Performance. This model shows that the independent variable in this study can explain the dependent variable as much as $74 \%$. In comparison, the remaining $26 \%$ is determined by others, not in the 
research Model 1. Model 2 explains the relationship between budget participation variables, cost management knowledge, and managerial performance.

The $\mathrm{R}$ square result is $50.2 \%$, while other variables determine the remaining $49.8 \%$, not in the Model 2 study.

Tabel 2.

The results of the determination coefficient test

\begin{tabular}{|c|c|c|c|}
\hline Model & $\mathbf{R}$ & $\begin{array}{c}\mathbf{R} \\
\text { Square }\end{array}$ & $\begin{array}{c}\text { Adjust.R } \\
\text { Square }\end{array}$ \\
\hline 1 & 0.860 & 0.740 & 0.714 \\
\hline 2 & 0.709 & 0.502 & 0.483 \\
\hline
\end{tabular}

\section{Hypothesis testing}

The following hypothesis can be tested using multivariable linear regression analysis. Based on the results of the $\mathrm{T}$ statistical test Based on the following equation:

$\mathrm{KM}=-2,503+2,009 \mathrm{PA}+1,729 \mathrm{PMB}-2,597 \mathrm{PA}$ * PMB

From the above equation, it can be described as follows:

1. Constant value $=-2,503$; score this constant states that the independent variable of budgetary participation is zero, then the managerial performance is $-2,503$

2. The PA coefficient value $=2.009$; The coefficient states that the budget participation variable has a positive direction. For every change in one unit of budget participation, then performance managerial has increased by 2.009 .

3. The value of the PMB coefficient $=1.729$; The coefficient states that the variable cost management knowledge has a positive direction, meaning that every change in one unit of cost management knowledge, then performance managerial has increased by 1.729 .

4. The coefficient value PA_PMB $=-2.597$;
The coefficient states that the moderating variable has the same direction negative, means that every change of a single unit of moderating variable, then performance managerial experience a decrease of 2,597 .

Based on the results of the T-test in table 4:10, it can be concluded as follows:

1. The effect of budget participation (PA) on managerial performance (KM) with a value of $t$ count $(\mathrm{PA})=2.194$, with a significance value of 0.031 , which is less than 0.05 , so it can be said that the budget participation variable (PA) has a positive effect significant to managerial performance (KM).

2. The influence of knowledge of cost management (PMB) on managerial performance $(\mathrm{KM})$ with $\mathrm{T}$-value $(\mathrm{PMB})=$ 2.898 , which has a significant value of 0.006 , it can be said that variable knowledge of cost management (PMB) has a positive and significant effect on managerial performance (KM).

3. The influence of the moderating variable (PA_PMB) resulting from the multiplication of $\mathrm{PA}$ and $\mathrm{PMB}$ on managerial performance $(\mathrm{KM})$ has a $\mathrm{t}$ value of -2.199 , which has a significant value of 0.031 . Thus, the variable moderation has a negative and significant effect on the relationship between budgetary participation and managerial performance.

Table 3.

Hypothesis Test Results

\begin{tabular}{|c|r|c|r|}
\hline Variable & Beta & $\mathbf{t}$ & Sig. \\
\hline PA & 2,009 & 2,194 & 0.031 \\
\hline PMB & 1,729 & 2,898 & 0.005 \\
& & & \\
\hline PA_PMB & $-2,597$ & $-2,199$ & 0.031 \\
& & & \\
\hline
\end{tabular}




\section{Moderation Test}

The results of the moderation test are to prove the results of the t-test which states that the moderating variable has a negative and significant effect. KM has a significant value of 0.000 which is smaller than 0.05 , so it can be said that it is significant. In the second output, PA_PMB, which is the multiplication result of $\mathrm{PA}$ * $\mathrm{PMB}$, has a significant value of 0.031, which is smaller than 0.05 , so it can be said that it is significant. Both are significant; it can be said that it is quasi moderation. Quasi moderation is a moderating variable that interacts with independent variables and becomes an independent variable (Hasan, 2018).

Table 4.

Moderation Test Results Model 1

\begin{tabular}{|c|c|c|c|}
\hline Var & Beta & $\mathbf{t}$ & Sig. \\
\hline PA & 0.005 & 0.050 & 0.960 \\
\hline PMB & 0.704 & 7,050 & 0,000 \\
\hline
\end{tabular}

\section{Model 2}

\begin{tabular}{|c|r|c|c|}
\hline Var & Beta & t & \multicolumn{1}{l|}{ Sig. } \\
\hline PA & 2,009 & 2,194 & 0.031 \\
\hline PMB & 1,729 & 2,898 & 0.005 \\
\hline PA_PMB & $-2,597$ & $-2,199$ & 0.031 \\
\hline
\end{tabular}

Effect of budget participation on managerial performance

Based on the results of the tests that have been done, it can be concluded that budget participation affects managerial performance. If a middle and lower-level manager has a high level of budget participation, it will produce high managerial performance or be said to be good to benefit the company.

This result means that a manager is ready to face environmental uncertainty to be used to make decisions. Budget participation will benefit the organization by providing suitable facilities so that it will increase performance. Efficient and effective budget participation can motivate employees to achieve organizational goals to improve existing performance in the company.

The results of this study have also been in line and consistent with previous research conducted by Agbejule and Saarikoski (2006), which has proven that there is a positive effect on budget participation managerial performance. Furthermore, this is also in line with Zubir et al. (2016) research, which states that budget participation positively affects managerial performance.

\section{Cost management knowledge moderates the effect} of budget participation on managerial performance

The effect of budget participation on managerial performance is significant, and the interaction effect between PA multiplied by $\mathrm{PMB}$ is significant. Both results are significant so that it can be said that the knowledge of cost management is a quasi moderator, which means that the variable of knowledge of cost management can be a pseudo-variable. Thus, this variable has two possibilities: moderating the relationship between budget participation variables and managerial performance variables. The second possibility is that the variable cost management knowledge interacts with managerial performance variables as independent variables.

This research is in line with the research conducted by Hasan (2018), which states that knowledge of cost management is used so that a manager can predict for the short and long term. Namely, by reducing the costs that the company will issue through streamlining necessary things and making goods that have no economic value become goods with economic value. 
Hasan (2018) also states that knowledge of cost management is a quasimoderator because cost management knowledge moderates the effect of budget participation on managerial performance. Thus, the higher the knowledge of cost management of a department/work unit in budgetary participation towards the goals to be achieved, the managerial performance of the department/work unit will also increase.

If in performance theory, as Blumberg and Pringle (1982) stated, a high capacity level means that the willingness level will be high and the opportunity will be higher. Knowledge of cost management without budget participation will reduce managerial performance. Therefore in this study is not in line with the research of Farahmita (2013).

In previous research, Agbejule and Saarikoski (2006) used the theoretical framework described by Blumberg and Pringle (1982). This research shows that three dimensions, namely capacity, willingness, and opportunity, state that if the manager's knowledge of cost management increases, the effect of budget participation is that managerial performance will also be more positive.

The research of Agbejule and Saarikoski (2006) does not explain the evidence of the theory put forward by Blumberg and Pringle (1982) in their research so that this study attempts to prove the relationship between the three dimensions put forward by Blumberg and Pringle (1982), namely capacity, willingness, and opportunity. Thus, this study is not in line with those research. It is also not in line with Zubir et al.'s (2016) research, which states that knowledge of cost management as a moderation variable can moderate the relationship between budgetary participation and managerial performance.

\section{CONCLUSION}

Based on the results of testing and discussion that have been carried out, it can be concluded that the results of this study prove that budgetary participation has a positive effect on managerial performance. Furthermore, these results prove that higher budget participation will improve managerial performance. This study also proves that knowledge of cost management is a quasi-moderator that modifies the relationship between budget participation and managerial performance.

This study proves that the higher the knowledge of cost management in budget participation towards achieving the goals, the higher the managerial performance. However, the modification is still pseudoprove the dimensions of capacity, willingness, and opportunity from Blumberg and Pringle's theory (1982).

\section{Limitations}

This research has several limitations, namely:

1. The object of this research is only in manufacturing companies and only focuses on East Java, so it is necessary to be careful in generalizing the results $o$ the research.

2. On research, this is only using only some of the factors for the theory of Blumberg and Pringle (1982), namely capacity.

\section{Suggestion}

Future research can use:

1. The object of research can be expanded not only to manufacturing companies and outside East Java but also to obtain a representative sample.

2. Other independent variables can be added to represent willingness dimensions, such as motivation and experience, and capacity dimension, namely knowledge of budget preparation and budget evaluation.

3. Performance appraisal from superiors can be used as a managerial performance measurement. 


\section{REFERENCES}

Agbejule, L., and Saarikoski, L. (2006). The Effect of Cost Management Knowledge On The Relationship Between Budgetary Participation and Managerial Performance. The British Accounting Review, 38 (1), 427- 440.

Angelina, N. (2018). The effect of environmental uncertainty the influence of managerial performance with management accounting systems as a moderation variable in manufacturing companies in Surabaya. (Thesis, Widya Mandala Catholic University Undergraduate Program, Surabaya, Indonesia) Obtained from https://repository.wima.ac.id/13805/, 10 September 2020, 17.32 WIB.

Aziz. (2014). Analysis of the Effect of Good Corporate Governance (GCG) on the Quality of Sustainability Report. Audit Journal and Accounting, Faculty of Economics, University of Jungpura, 3 (2), 65-84

Blumberg, M., and Pringle, C. (1982). The Missing Opportunity in Organizational Research: Some Implications for a Theory of Work Performance. Academy of Management Review.

Dharmanegara. (2018). Entrepreneurial Orientation, Business Strategy, and Small Medium Enterprise's Performance. International Journal of Academic Research in Business and Social Sciences.

Farahmita, A. (2013). Effect of Job Satisfaction and knowledge of Cost Management and Relationship between Participation Angreward with Managerial Performance. Journal of the National Accounting Simposium XVI Manado.

Ghozali, I. (2016). Multivariate Analysis Application with IBM SPSS 23 Program, 8th ed. Semarang: Diponegoro University Publishing Agency.

Hage, J., and Mintzberg, H. (1980). The Structuring of Organizations: A Synthesis of Research. Administrative Science Quarterly.
Hasan, H. (2018). The Role of Budgetary Control on Managerial Performance in Fertilizer Companies in Indonesia. Journal of Accounting Research, Organization, and Economics, 1 (2), 138-148

Mardiasmo. (2002). Public sector accounting Yogyakarta Journal.

Nafarin, M. (2013). Corporate Budgeting. Journal 10.

Narsa, I., and Yuniawati, R. (2003). The Influence of the Interaction Between Total Quality Management With Performance Measurement Systems And Reward Systems On Managerial. Journal of Accounting and Finance.

Nasution, A. (2005). Monetary cooperation in East Asia. Journal of Asian Economics.

Sadha, Stivanus. (2015) The influence of total quality management, budget systems, and reward systems on managerial performance at PT. KAI drop 8 Surabaya. (Thesis, Widya Mandala Catholic University Undergraduate Program, Surabaya, Indonesia). Obtained from https://repository.wima.ac.id/16347/, July 25, 2020, 18.26.

Sagala, R. (2009). Theoretical basis. Obtained from https://www.landasanteori.com, 30 August 2020, at 12:20 pm.

Sartika. (2017). Analysis of the Effect of the Performance Measurement System on Managerial Performance through Clarity of Roles and Psychological Empowerment as Variables Moderating. Journal of Accounting and Finance, 8 (1), 115.

Scully, J., Kirkpatrick, S., and Locke, E., (1995). Locus of knowledge as a determinant of the effects of participation on performance, affect, and perceptions. Organizational Behavior and Human Decision Processes, 276-288.

Shields, M., and Young, M. (1998). Managing innovation costs: a study of costconscious awareness by R\&D professionals. Journal of Management Accounting Research, 6, 175-196. 
Setiawaty, A. (2016). The Effect of Good Corporate Governance Mechanism on Banking Performance with Risk Management as an Intervening Variable. Journal of Economics and Management.

Tambun, S. (2013). Data Processing Techniques and Interpretation of Research Results Using SPSS Program For Variable Moderating. Jakarta: University Publishing Agency 17 August 1945.

Widyawati, N. (2017). The Effect of Trust and
Commitment and Service Marketing Mix on Customer Loyalty in Zakiah Hotels Medan. Journal of Economics and Finance.

Zubir, Hasan, A., and Basri, Y. (2016). The Effect of Budget Participation on Managerial Performance with Job Relevant Information (JRI) and Cost Management Knowledge as a Moderating Variable (Empirical Study on Banking Companies in Pekanbaru. Journal Economics, 24(3). 